\title{
Combining Ability and Gene Action of Tropical Maize (Zea mays L.) Inbred Lines under Low and High Nitrogen Conditions
}

\author{
Mafouasson Apala Hortense Noëlle ${ }^{1}$, Kenga Richard ${ }^{1}$, Gracen Vernon ${ }^{2}$, Yeboah Agyei Martin ${ }^{2}$, \\ Mahamane Nasser Laouali ${ }^{3}$, Tandzi Ngoune Liliane ${ }^{1} \&$ Ntsomboh-Ntsefong Godswill $^{1}$ \\ ${ }^{1}$ Institut de Recherche Agricole pour le Développement (IRAD), Yaoundé, Cameroon \\ ${ }^{2}$ West Africa Centre for Crop Improvement (WACCI), College of Basic and Applied Sciences, University of \\ Ghana, Accra, Ghana \\ ${ }^{3}$ Institut National de la Recherche Agronomique du Niger (INRAN/CERRA), Maradi, Niger \\ Correspondence: Mafouasson Apala Hortense Noëlle, Institut de Recherche Agricole pour le Développement \\ (IRAD), P.O. Box 2123 Yaounde, Cameroon. Tel: 237-222-232-644. Fax: 237-222-233-538. E-mail: \\ mafouasson@yahoo.fr
}

Received: February 2, 2017

Accepted: March 1, 2017 Online Published: March 15, 2017

doi:10.5539/jas.v9n4p222

URL: https://doi.org/10.5539/jas.v9n4p222

\begin{abstract}
This study was conducted to determine combining ability and gene action in elite maize inbred lines under low and high soil nitrogen conditions for hybrid breeding. Forty two tropical inbred lines (three testers and 39 lines) were crossed using line $\times$ tester mating design. The resulting 117 F1 hybrids, along with 4 hybrids used as checks, were evaluated using an $11 \times 11$ lattice design with two replications for grain yield and yield related traits during the 2012 and 2013 cropping seasons at two sites (Mbalmayo and Nkolbisson). Results revealed predominant additive gene effect under high soil nitrogen $(\mathrm{N})$ conditions. Non-additive gene effect influenced grain yield under low soil and thus could be exploited for hybrid development. Under high $\mathrm{N}$ conditions inbred lines CLYN246, J16-1, CLWN201, TL-11-A-1642-5, CLQRCWQ26 and 1368 were good general combiners. Lines CML 343, ATP S6 20-Y-1, CLWN201, 1368, ATP S9 30 Y-1 and CLQRCWQ26 were good general combiners for grain yield under low $\mathrm{N}$. They could be used to develop low $\mathrm{N}$ tolerant varieties. Different single cross hybrid combinations were identified for high grain yields under both low and high $\mathrm{N}$ conditions. The selected lines and single cross hybrids are a useful source of valuable genetic material for future maize hybrid breeding or direct production under low $\mathrm{N}$.
\end{abstract}

Keywords: maize, hybrids, low nitrogen, combining ability, line $\times$ tester

\section{Introduction}

Maize (Zea mays L.) is one of the most important and widely grown cereal crops in West and Central Africa. In sub-Saharan Africa (SSA), maize is a staple food for an estimated $50 \%$ of the population (IITA, 2014) and accounts for about $15 \%$ of the calorific intake of the population (Badu-Apraku \& Akinwale, 2011). World maize production is estimated at about 872 million tonnes, planted on over 177 million hectares (NUEweb, 2012). African production represents only $7.9 \%$ of the world's production. This may be because average maize grain yield in Africa is still low compared to developed countries, especially under small-scale farmers' conditions where many stresses are present.

In Cameroon, despite the increase in maize production from 966,000 tonnes in 2004 to 1,647,036 tonnes in 2013 (FAOSTAT, 2014), there is a deficit between domestic demand and supply. Failure of the national production to meet the needs of Cameroonian households may be attributed to the effects of various biotic and abiotic constraints including low soil fertility, soil acidity, poor crop management practices, low adoption of improved varieties, and pest and disease damages (Ngoko et al., 2002; Nguimgo et al., 2003; The et al., 2013). Low soil fertility, particularly soil nitrogen deficiency, is a serious concern of maize farmers in Cameroon (Hauser \& Nolte, 2002; Ngoko et al., 2002; Nguimgo et al., 2003; The et al., 2013). The problem is worsened by the lack of availability and/or high prices of mineral fertilizers in the country. In addition, continuous cropping over decades with no measures in place to regenerate the soil's productivity has contributed to decreased soil fertility and, consequently, the low level of maize production in Cameroon. 
One effective strategy to reduce fertilizer requirements is to develop maize genotypes with high nitrogen use efficiency and high yield potential. Genotypes with high yield potential are also needed to support the rapidly growing population and may provide incentives to farmers who are trying to make modest increase in nitrogen application in their maize fields.

In maize breeding programs, analysis of general combining ability (GCA) and specific combining ability (SCA) are essential to identify best inbred lines for hybrid development and hybrid combinations with better specific combining ability (Abrha et al., 2013; Girma et al., 2015). Combining ability is an effective tool which gives useful genetic information for the choice of parents in terms of their performance in series of crosses (Sprague \& Tatum, 1942). The development of inbreds having high combining abilities has a fundamental role in the efficient use of heterosis (Vasal et al., 1992). Crossing between inbred lines with high specific combining ability can improve tolerance to different stresses and superior hybrids with high yield production under stress condition (Betràn et al., 2003; Vasal et al., 1997).

Various biometrical approaches are available to assess the breeding value of potential parents and to assess the genetics of the traits of interest. Line $\times$ tester analysis (Kempthrone, 1957) is an approach often employed to understand the genetic basis of a given character and combining ability of parents and hybrids (Tamilarasi et al., 2010). The line $\times$ tester analysis has been widely used by plant breeders. It is used to breed both self and cross pollinated plants as well as estimating favourable parents, crosses and their general and specific combining ability (Aly, 2013; Majid et al., 2010). It is useful in deciding the relative ability of female and male lines to produce desirable hybrid combinations (Kempthrone, 1957) and also provides information on genetic components. It enables breeders to choose appropriate breeding methods for hybrid varieties or cultivar development programmes. This design has been efficiently used for estimating breeding values of maize inbred lines and for determining the gene action that controls quantitatively inherited traits (Sofi \& Rather, 2006) such as low $\mathrm{N}$ tolerance.

Genetic studies have been conducted on maize genotypes under low $\mathrm{N}$ using different sources of genetic material (Badu-Apraku et al., 2013; Betràn et al., 2003; De Souza et al., 2008; Makumbi et al., 2011; Meseka et al., 2006; Meseka et al., 2013; Miti, 2007; Pswarayi \& Vivek, 2008). However, information on gene action conditioning grain yield under low $\mathrm{N}$ has been contradictory. The contradictory results obtained by researchers might be due to the $\mathrm{N}$ stress level (testing environments) under which the genotypes were tested and/or genotypic differences among sets of genotypes used in the studies (Mosisa, 2008). Many of these studies were conducted using extra early maturing maize lines. Further studies are therefore necessary in order to examine the genetic effects conditioning grain yield and other traits under both low and high $\mathrm{N}$ conditions using lines with intermediate maturity cycle. Moreover, the Cameroonian National Maize Breeding Program, in collaboration with the International Institute of Tropical Agriculture (IITA), has developed maize inbred lines adapted to the different agro-ecological zones of Cameroon and to different stresses such as acid soils, drought and Striga. However, very little work has been done on low soil nitrogen. Futhermore, inbreds from IITA, CIMMYT and some African breeding programs have been introduced and there is need to use the national and these newly introduced maize inbreds in studies for combining ability and heterosis in relation to interesting traits under low soil nitrogen and optimum growing conditions.

This study was conducted to identify high yielding hybrids tolerant to low $\mathrm{N}$ soils, determine the combining abilities and mode of gene action of intermediate maturing inbred lines for hybrid development under low soil $\mathrm{N}$ conditions.

\section{Materials and Methods}

\subsection{Plant Material}

Forty-two intermediate to late maturating inbred lines (39 lines and 03 testers) were used in the study. These lines were provided by IRAD Cameroon, IITA and CIMMYT (Table 1). Thirty-nine inbred lines were crossed with three testers (87036, Exp1 24 and 9071) in a line $\times$ tester scheme to obtain 117 hybrid combinations. In addition, 4 hybrids $\left(87036 \times \operatorname{Exp} 124,9071 \times \operatorname{Exp} 124,87036 \times 9071\right.$ and $88069 \times$ Caminbgp $\left._{1} 17\right)$ were included as checks to make a total of 121 entries. The hybrid $87036 \times \operatorname{Exp} 124$ is a high yielding hybrid released in Cameroon and adapted to the Humid Forest Zone of Cameroon. Exp1 $24 \times 9071$ is also a high yielding hybrid, developed from a cross between tropical lowland $\times$ temperate converted inbreds.

\subsection{Experimental Sites}

The study was conducted at two locations of the Humid Forest Zone with bimodal rainfall, namely Nkolbisson and Mbalmayo. Nkolbisson is located at $11^{\circ} 36^{\prime} \mathrm{E}$ and $3^{\circ} 44^{\prime} \mathrm{N}, 5 \mathrm{~km}$ from the main capital city 'Yaoundé'. The 
altitude is $650 \mathrm{~m}$ above sea level (asl). The annual rainfall is $1560 \mathrm{~mm}$ with bimodal distribution. The average daily temperature is $23.5^{\circ} \mathrm{C}$. The soil is sandy clay with $\mathrm{pH}$ (water) of 4.52 , CEC of $4.79 \mathrm{Cmol}(+) \mathrm{kg}^{-1}$ and AL of $0.30 \mathrm{Cmol}(+) \mathrm{kg}^{-1}$. The main cropping system is maize/groundnut/cassava as sole cropping or mix cropping (The et al., 2013).

Mbalmayo is located at $11^{\circ} 30^{\prime} \mathrm{E}$ and $3^{\circ} 31^{\prime} \mathrm{N}, 45 \mathrm{~km}$ from Yaounde. The altitude is $641 \mathrm{~m}$ asl. The mean annual rainfall varies from 1017 to $1990 \mathrm{~mm}$ with bimodal distribution. The mean monthly temperature varies from $25^{\circ} \mathrm{C}$ to $22{ }^{\circ} \mathrm{C}$. The soil is sandy clay. The agricultural practice is based on shifting cultivation techniques. The main crops are cassava and cocoyam grown as sole or intercropped with groundnut or maize (Tchienkoua, 1996).

\subsection{Site Preparation and Soil Analysis}

Low $\mathrm{N}$ plots were established by soil depletion of available nitrogen. Soil $\mathrm{N}$ depletion consisted of planting maize uniformly in the field at a very high density without any fertilizer application for many growing seasons.

Soil samples collected from the two locations before each cropping season were analyzed for selected physical and chemical properties at the soil laboratory of the International Institute of Tropical Agriculture (IITA) Cameroon.

\subsection{Experimental Design and Management}

The $121 \mathrm{~F}_{1}$ hybrids were evaluated during 2012 and 2013 in three cropping seasons under high $\mathrm{N}$ level $(100 \mathrm{~kg}$ $\left.\mathrm{ha}^{-1}\right)$ and low $\mathrm{N}\left(20 \mathrm{~kg} \mathrm{~h}^{-1}\right)$. At each $\mathrm{N}$ level, the 121 hybrids were arranged in an $11 \times 11$ lattice design. The experimental unit consisted in a single row of $5 \mathrm{~m}$ at Mbalmayo and single $4 \mathrm{~m}$ at Nkolbisson. Hybrids were planted in 2 replications. The spacing between rows was $0.75 \mathrm{~m}$ and $0.5 \mathrm{~m}$ between hills within a row. Three seeds were planted in a hill and thinned after emergence to 2 plants, for a final density of 53,330 plants per hectare.

Split fertilization was done on each plot. On the low N plot, the first application in $\mathrm{kg}^{-1} \mathrm{~h}^{-1}$ consisted of $10 \mathrm{~N}, 24$ $\mathrm{P}_{2} \mathrm{O}_{5}$ per hectare and $14 \mathrm{~K}_{2} \mathrm{O}$ per hectare, 10 days after planting, and the second dose consisted of $10 \mathrm{~N}$, applied 30 days after planting. On the high $\mathrm{N}$ plot, the first application consisted of a mixture of $35 \mathrm{~N}, 24 \mathrm{P}_{2} \mathrm{O}_{5}$ and 14 $\mathrm{K}_{2} \mathrm{O}$ per hectare, applied 10 days after planting and the second dose was $65 \mathrm{~N}$ per hectare, applied 30 days after planting. The trials were kept clean of weeds throughout the growing cycle by spraying an herbicide with active ingredient $750 \mathrm{~g} / \mathrm{kg}$ of Atrazine and $40 \mathrm{~g} / \mathrm{kg}$ of Nicosulfuron at the early stage of maize growth, and later by hand weeding.

\subsection{Data Recorded}

The various characteristics were recorded viz. anthesis date (AD) and silking date (SD) were recorded as 'number of days after planting', when $50 \%$ of plants were shedding pollen and silking, respectively. The anthesis-silking interval (ASI) was calculated as silking date minus anthesis date. Leaf chlorophyll content (\%) was determined in four randomly selected plants from each experimental unit and two measurements were obtained per plant on the ear leaf, using a portable Minolta chlorophyll meter (SPAD-502, MINOLTA) one week after silking.

Ear leaf area was determined after silking from the leaf immediately below the upper ear on four randomly selected plants in each plot, and was obtained by multiplying maximum leaf width by leaf length by 0.75 (Montgomery, 1911; Giauffret et al., 1997). Leaf senescence was scored 10 and 12 weeks after planting on a scale from 0 to 10 , dividing the percentage of the estimated total leaf area below the ear that is dead by 10 . A score of $1=$ less than $10 \%$ dead leaf and $10=$ more than $90 \%$ dead leaf. Plant height was measured as the distance from the base of the plant to the height of the first tassel branch.

At harvest, the number of ears per plant was computed as the proportion of total number of ears divided by the number of plants harvested in each experimental unit. Ear aspect was scored on a scale of 1 to 5, where 1 corresponded to clean, uniform, large, and well-filled ears and 5 was the rotten, variable, small, and partially filled ears. At maturity, each row was harvested separately and ear weight was measured for each plot. Grain yield adjusted to $15 \%$ grain moisture was calculated in $\mathrm{kg} \mathrm{ha}^{-1}$ for every entry from the data of fresh ear weight per plot under high $\mathrm{N}$. On low $\mathrm{N}$ plots, grain yield was computed from shelled grain weight.

\subsection{Statistical Analysis}

The data collected were analyzed using general linear model (GLM) procedure in SAS (SAS institute, version 9.2, 2008). Entry means adjusted for block effects were analyzed according to lattice design (Cochran \& Cox, 1960). Each environment was defined as year $\times$ season $\times$ site $\times$ nitrogen treatment. The analysis of variance (ANOVA) for each environment and the combined ANOVA were computed with PROC GLM procedure in SAS 
using the RANDOM statement with the TEST option. Environment effects were treated as random effects and genotypes as fixed effects. The effects of environment on all the measured traits were evaluated through different interaction estimates. Line $\times$ tester analysis (Kempthrone, 1957) was done for low $\mathrm{N}$ environments, high and across environments to partition the mean square due to crosses into lines, testers and line $\times$ tester interaction effects for traits that showed significant differences among crosses. This analysis was done with PROC GLM in SAS using a RANDOM statement with the TEST option (SAS 2008). The relative importance of GCA versus SCA on progeny performance was calculated as the ratio between sum of squares due to GCA or SCA and total sum of squares (GCA and SCA sums of squares) (Beck et al., 1990; Pswarayi \& Vivek, 2008).

\section{Results}

\subsection{Analysis of Variance and Hybrid Mean Performance}

Across the ten research environments, highly significant differences $(\mathrm{p}<0.01)$ were observed among the hybrids and between environments for all the measured traits. Hybrid $\times$ environment interaction was significant for all traits suggesting that the relative performance of a hybrid was not consistent across environments.

Under low $\mathrm{N}$ environments, significant differences were observed among the hybrids for all traits. The differences between all low $\mathrm{N}$ environments were significant $(\mathrm{p}<0.05)$ for grain yield and ear leaf chlorophyll content and highly significant for days to silking, anthesis-silking interval, leaf area and plant height. Across low $\mathrm{N}$ environments, grain yield ranged from $1539.3 \mathrm{~kg} \mathrm{ha}^{-1}(\mathrm{CML} 358 \times 9071)$ to $3770.51 \mathrm{~kg} \mathrm{ha}^{-1}$ (TL-11-A-1642-5 $\times$ Exp1 24), with a mean of $2721.9 \mathrm{~kg} \mathrm{ha}^{-1}$ (Table 2). Days to silking ranged from 62.50 to 71.70 with a mean of 66.98 days. Anthesis-silking interval ranged from 1.9 days to 4.9 days with a mean of 3.18 days. Leaf area varied from 404.93 to $626.59 \mathrm{~cm}^{2}$ with a mean of $525.59 \mathrm{~cm}^{2}$. Leaf chlorophyll content varied from $31.50 \%$ to $46.22 \%$, with a mean of $40.80 \%$ and higher values were observed among the 20 best hybrids. Mean for plant height was $163.46 \mathrm{~cm}$, ranging from $135 \mathrm{~cm}$ to $182.92 \mathrm{~cm}$ and ear aspect ranged from 2.35 to 4.05 with a mean of 3.05 (Table 2). Across low N environments, five hybrids yielded more than $3500 \mathrm{~kg}^{-h^{-1}}{ }^{-1}$. These were TL-11-A-1642-5 $\times \operatorname{Exp} 124\left(3770.51 \mathrm{~kg} \mathrm{ha}^{-1}\right)$, CLWN201 $\times 87036\left(3609.2 \mathrm{~kg} \mathrm{ha}^{-1}\right)$ ATP S6 $20 \mathrm{Y}-2 \times \operatorname{Exp} 124\left(3556.47 \mathrm{~kg} \mathrm{ha}^{-1}\right)$, J16-1 × Exp1 $24\left(3516.41 \mathrm{~kg} \mathrm{ha}^{-1}\right)$, ATP S9 $30 \mathrm{Y}-1 \times$ Exp1 $24\left(3514.44 \mathrm{~kg} \mathrm{ha}^{-1}\right)$, CLYN246 $\times 87036(3512.06 \mathrm{~kg}$ $\mathrm{ha}^{-1}$ ) (Table 2). The two highest yielding hybrids were TL-11-A-1642-5 $\times$ Exp1 24 and CLWN201 $\times 87036$ with mean grain yields of $3770.51 \mathrm{~kg} \mathrm{ha}^{-1}$ and $3609.2 \mathrm{~kg} \mathrm{ha}^{-1}$ respectively. None of the four hybrid checks figured among the 20 best hybrids under low $\mathrm{N}$.

On the other hand, mean yield varied under high $\mathrm{N}$ environments from $3026.5 \mathrm{~kg} \mathrm{ha}^{-1}$ for J18-1 $\times 9071$ to 6588.8 $\mathrm{kg} \mathrm{ha}^{-1}$ for TL-11-A-1642-5 $\times 87036$, with an overall mean of $4887.18 \mathrm{~kg} \mathrm{ha}^{-1}$ (Table 3). Days to $50 \%$ silking ranged from 61.2 to 60.40 with a mean of 62.4 days. Mean anthesis-silking interval varied from 1.6 to 3.1 days with a mean of 2.26 days (Table 3). Leaf area ranged from $472.70 \mathrm{~cm}^{2}$ to $772.06 \mathrm{~cm}^{2}$ with a mean of $630.63 \mathrm{~cm}^{2}$. Chlorophyll concentration varied from $43.02 \%$ to $55.90 \%$ with a mean of $49.96 \%$. Mean of plant height was 182.27, ranging from 153.23 to $210.07 \mathrm{~cm}$. Mean of ear aspect ranged from 1.85 to 3.50 , with a mean of 2.5 (Table 3). Five hybrids yielded more than $6000 \mathrm{~kg} \mathrm{ha}^{-1}$ under high $\mathrm{N}$. These are TL-11-A-1642-5 $\times 87036$ $\left(6588.84 \mathrm{~kg} \mathrm{ha}^{-1}\right)$, CLYN246 $\times 87036\left(6584.97 \mathrm{~kg} \mathrm{ha}^{-1}\right)$, TZ-STR-133 $\times 87036\left(6393.32 \mathrm{~kg} \mathrm{ha}^{-1}\right)$, CLWN201 $\times$ Exp1 $24\left(6152.26 \mathrm{~kg} \mathrm{ha}^{-1}\right)$ and J16-1 $\times$ Exp1 $24\left(6048.74 \mathrm{~kg} \mathrm{ha}^{-1}\right)($ Table 3). The highest yielding checks among the four evaluated were $87036 \times \operatorname{Exp} 124\left(5169.43 \mathrm{~kg} \mathrm{~h}^{-1}\right)$ and Exp1 $24 \times 9071\left(5262.24 \mathrm{~kg} \mathrm{ha}^{-1}\right)$ but these hybrids were not among the 20 best hybrids selected under high $\mathrm{N}$ conditions.

Line $\mathrm{x}$ tester analysis revealed highly significant $(\mathrm{p}<0.01)$ line general combining ability $(\mathrm{GCA})$ mean squares for all traits under low N environments, (Table 4). Means squares of tester GCA were significantly different for all traits except days to silking and anthesis-silking interval. There were highly significant differences between specific combining ability (SCA) mean squares for all traits except leaf senescence and plant height (Table 4). More still, the contribution of SCA to the total sum of squares of crosses under low $\mathrm{N}$ was higher compared to the contribution of GCA for grain yield, anthesis-silking interval, leaf chlorophyll content and ear aspect, while contribution of SCA was lower than GCA for days to silking, leaf senescence and plant height (Table 4).

Under high $\mathrm{N}$ conditions, line $\times$ tester analysis, revealed significant $(\mathrm{p}<0.05)$ line GCA mean squares for anthesis-silking interval and highly significant $(\mathrm{p}<0.01)$ line GCA values for all the other measured traits (Table 5). Meanwhile, tester GCA mean square was significant for all traits except anthesis-silking interval (Table 5). SCA mean squares were significant for grain yield, days to silking, leaf area and ear aspect. The contribution of GCA effect to the sum of squares of crosses was higher than the contribution of SCA for all traits except anthesis-silking interval (Table 5). 


\subsection{General Combining Ability Effects}

Six lines had positive, significant GCA effects for grain yield. These are CML 343 (522.26), ATP S6 20-Y1 (504.46), CLWN201 (483.80), 1368 (468.23), ATP S9 30 Y-1 (436.48) and CLQRCWQ26 (396.45) (Table 6). The line with the best GCA effects for grain yield was CML 343. The desired line GCA value for days to silking and anthesis-silking was negative, therefore, the best line for GCA for days to silking were V 351-1/6 and CLA 17 with a GCA effect of -3.23 and -2.46 , respectively. The same lines V351-1/6 and CLA 17 had the best GCA effects for anthesis-silking interval ( -0.81 and -0.58 respectively). The two best combiners for leaf area, with positive significant GCA effects, were CLQRCWQ26 (43.97) and ATP S5 31-Y-2 (35.98). Moreover, the lines with best GCA for plant height were ATP S9 30 Y-1 (9.31) and 5012 (8.10). For ear aspect, three lines had the best GCA of -0.2. These are CLWN 201, CLYN246 and ATP S6 20 Y-2. Two out of the three testers had positive GCA effects for grain yield under low N. These are 87036 (72.19) and Exp1 24 (59.95). The tester 9071 had a negative GCA value (Table 6).

For days to silking, only 9071 had negative GCA effect (-0.07) while for anthesis-silking interval, 87036 and Exp1 24 had negative GCA (-0.02 and -0.11 , respectively), indicating good general combining ability for this trait under low N. The testers 87036 and Exp1 24 also had positive GCA effects for ear leaf area indicating good combining ability for this trait while 9071 GCA effect was negative. For leaf chlorophyll content, 87036 had the best GCA (0.81) while for leaf senescence EXP1 24 was the tester with best GCA (-0.18). For plant height, the tester 87036 had the best GCA (6.75). The testers $87036(-0.06)$ and Exp1 $24(-0.06)$ both had a good GCA effect for ear aspect (Table 6). Under high $\mathrm{N}$ conditions, the six best lines with positive, significant GCA effects for grain yield were CLYN246 (982.75), J16-1 (728.75), CLWN201 (720.74), TL-11-A-1642-5 (675.86), CLQRCWQ26 (640.10) and 1368 (546.51) (Table 6).

\subsection{Specific Combining Ability Effects for Grain Yield}

The cross between line ATP S6 20 Y-2 and Exp1 24 had the highest positive SCA effect (679.45) for grain yield under low N environments (Table 6). This cross was followed by TL-11A-1642-5 $\times$ Exp1 24 (648.39) and CML $494 \times 9071$ (626.40). The first two crosses, ATP S6 20 Y-2 $\times$ Exp1 24 and TL-11-A -1642- $5 \times$ Exp1 24, with the best SCA effects, were among the highest yielding hybrids. However, the third best cross CML494 $\times 9071$ and other crosses such as CML358 $\times$ Exp1 24, M131 $\times 9071$ were among crosses with highest SCA for yield but they were not among the highest yielding hybrids. Moreover, $1368 \times$ Exp1 24 and ATP S6 20 Y-1 $\times 87036$ had negative SCA (-114,1 and -98 respectively) but yielded more than $3000 \mathrm{~kg} \mathrm{ha}^{-1}$ while many other crosses with high positive SCA did not yield up to this level. Under high $\mathrm{N}$ environment, the best crosses with the highest positive SCA effects were 4001STR $\times 9071$ (986.82), followed by J18-1 $\times 87036$ with an SCA of 905.58 and TZ-STR-133 $\times 87036$ with 893.04 as SCA (Table 6). All these were high yielding hybrids, with two of them (TZ-STR-133 $\times 87036$ and 4001STR $\times$ 9071) being among the 20 best yielding under high $\mathrm{N}$ conditions. 
Table 1. Origin, grain colour and main characteristics of maize inbred lines, testers and hybrid checks used in the study

\begin{tabular}{|c|c|c|c|c|}
\hline No & Lines & Origin & Grain color & Main characteristics \\
\hline 1 & Cla 17 & CIMMYT & $\mathrm{Y}$ & Tolerant to acid soils. Heterotic to Cla 18 \\
\hline 2 & 9450 & IITA & $\mathrm{Y}$ & Converted from B73 and tolerant to low $\mathrm{N}$ \\
\hline 3 & 1368 & IITA & W & Extracted from pop 21 \\
\hline 4 & M 131 & IRAD & W & Mid altitude adaptation and tolerant to low N. \\
\hline 5 & 88094 & IRAD & W & Mid altitude adaptation and tolerant to low N. \\
\hline 6 & $\mathrm{~J} 18-1$ & WACCI & W & Tolerant to drought \\
\hline 7 & 88069 & IRAD & Y & Mid altitude converted to lowland adaptation. \\
\hline 8 & Entrada 29 & CIMMYT & $\mathrm{W}$ & Tolerant to Aluminium. \\
\hline 9 & CML 358 & CIMMYT & Y & Tolerant to Aluminium. \\
\hline 10 & Entrada 3 & CIMMYT & $\mathrm{W}$ & Tolerant to Aluminium. \\
\hline 11 & CML 254 & CIMMYT & $\mathrm{W}$ & Tolerant to Aluminium. \\
\hline 12 & 5012 & IITA & $\mathrm{W}$ & Temperate converted to tropical adaptation. \\
\hline 13 & Cam inb gp1 17 & IRAD & Y & Tolerant to acid soil \\
\hline 14 & 9848 & IITA & $\mathrm{Y}$ & Temperate converted to tropical adaptation. \\
\hline 15 & CLA 18 & CIMMYT & $\mathrm{Y}$ & Tolerant to $\mathrm{Al}$ acid soil. \\
\hline 16 & ATP S9 30 Y-1 & IRAD & $\mathrm{Y}$ & Extracted from acid tolerant maize population. \\
\hline 17 & ATP S5 26 Y-1 & IRAD & $\mathrm{Y}$ & Extracted from acid tolerant maize population. \\
\hline 18 & KU1414 & IITA & $\mathrm{Y}$ & Tolerant to low $\mathrm{N}$ \\
\hline 19 & 5057 & IITA & W & Temperate line converted: Susceptible to drought, striga. \\
\hline 20 & ATP S6 20 Y-1 & IRAD & $\mathrm{Y}$ & Extracted from acid tolerant maize population. \\
\hline 21 & ATP S8 30 Y-3 & IRAD & $\mathrm{Y}$ & Extracted from acid tolerant maize population. \\
\hline 22 & TZMI 102 & IITA & $\mathrm{W}$ & \\
\hline 23 & J16-1 & CIMMYT & $\mathrm{W}$ & Tolerant to drought \\
\hline 24 & CLYN246 & CIMMYT & $\mathrm{Y}$ & Tolerant to low $\mathrm{N}$ \\
\hline 25 & CML395 & CIMMYT & W & Susceptible to low N \\
\hline 26 & CML494 & CIMMYT & W & Susceptible to low N \\
\hline 27 & CML165 & CIMMYT & $\mathrm{Y}$ & Susceptible to low N \\
\hline 28 & CLQRCWQ26 & CIMMYT & W & Susceptible to low N \\
\hline 29 & CML451 & CIMMYT & W & Susceptible to low N \\
\hline 30 & $V-351-1 / 6$ & CIMMYT & W & Drought tolerant \\
\hline 31 & V-481-73 & CIMMYT & W & Drought tolerant \\
\hline 32 & TZ-STR-133 & IITA & W & \\
\hline 33 & TL-11-A-1642-5 & CIMMYT & W & \\
\hline 34 & Ku 1409 & IITA & Y & Tolerant to low N and downy mildew. From Swan pop \\
\hline 35 & ATP S6-20-Y-1 & IRAD & $\mathrm{Y}$ & Extracted from acid tolerant maize population. \\
\hline 36 & CLWN201 & CIMMYT & W & Tolerant to low $\mathrm{N}$ \\
\hline 37 & CML444 & CIMMYT & W & Tolerant to low $\mathrm{N}$ \\
\hline 38 & CML343 & CIMMYT & & Tolerant to low $\mathrm{N}$ \\
\hline 39 & 4001STR & IITA & $\mathrm{Y}$ & Tolerant to low N, extracted from population 28 \\
\hline \multicolumn{5}{|c|}{ Testers } \\
\hline 40 & 87036 & IRAD & $\mathrm{W}$ & Mid altitude line converted to low-land \\
\hline 41 & Exp1 24 & IRAD & $\mathrm{W}$ & Tuxpeno background. Good combiner. \\
\hline 42 & 9071 & IITA & W & Converted from N28 and good combiner \\
\hline
\end{tabular}

Note. $\mathrm{W}=$ white; $\mathrm{Y}=$ yellow; IITA $=$ International Institute of Tropical Agriculture; CIMMYT $=$ International Centre for Maize and Wheat Improvement. 
Table 2. Means for grain yield and other agronomic traits of selected best 20 hybrids and checks in low $\mathrm{N}$ environments

\begin{tabular}{|c|c|c|c|c|c|c|c|c|c|}
\hline Hybrids & $\begin{array}{l}\text { YIELD } \\
\left(\mathrm{kg} \mathrm{ha}^{-1}\right)\end{array}$ & $\begin{array}{l}\text { DTS } \\
\text { (days) }\end{array}$ & $\begin{array}{l}\text { ASI } \\
\text { (days) }\end{array}$ & $\begin{array}{l}\text { LAREA } \\
\left(\mathrm{cm}^{2}\right)\end{array}$ & $\begin{array}{l}\text { CHLORO } \\
(\%)\end{array}$ & LSENE (1-9) & $\begin{array}{l}\text { PHT } \\
\text { (cm) }\end{array}$ & EA (1-5) & $\begin{array}{l}\text { Index } \\
(\%)\end{array}$ \\
\hline TL-11-A-1642-5 × Exp1 24 & 3770.51 & 66.70 & 2.60 & 531.77 & 41.47 & 2.90 & 155.78 & 2.40 & 30.42 \\
\hline CLWN201 × 87036 & 3609.2 & 66.10 & 4.20 & 504.41 & 41.62 & 3.80 & 175.60 & 2.35 & 33.51 \\
\hline ATP S6 20 Y-2 × Exp1 24 & 3556.47 & 64.50 & 2.90 & 589.33 & 41.85 & 3.20 & 158.67 & 2.70 & 31.00 \\
\hline J16-1 × Exp1 24 & 3516.41 & 65.70 & 3.80 & 601.41 & 39.95 & 3.20 & 162.07 & 2.55 & 41.87 \\
\hline ATP S9 30 Y-1 × Exp1 24 & 3514.44 & 66.40 & 3.10 & 585.44 & 44.16 & 3.70 & 167.13 & 2.50 & 22.04 \\
\hline CLYN246 × 87036 & 3512.06 & 65.00 & 2.70 & 602.02 & 41.42 & 3.28 & 173.73 & 2.65 & 46.67 \\
\hline ATP S9 30 Y-1 × 87036 & 3464.15 & 66.60 & 2.70 & 536.29 & 41.98 & 3.70 & 179.73 & 2.95 & 33.34 \\
\hline CLWN201 × Exp1 24 & 3415.18 & 65.30 & 2.50 & 491.70 & 41.09 & 3.50 & 153.90 & 2.75 & 44.49 \\
\hline ATP S6-20-Y-1 × Exp1 24 & 3365.33 & 64.00 & 2.70 & 556.50 & 34.25 & 3.40 & 162.90 & 2.90 & 40.60 \\
\hline Entrada $29 \times$ Exp1 24 & 3321.12 & 66.20 & 3.30 & 594.61 & 42.86 & 2.85 & 174.23 & 2.50 & 34.40 \\
\hline CML165 × 87036 & 3319.69 & 66.50 & 3.10 & 585.71 & 44.38 & 3.60 & 174.97 & 2.60 & 36.83 \\
\hline $1368 \times 87036$ & 3315.63 & 66.70 & 3.50 & 574.84 & 41.11 & 3.45 & 173.83 & 2.65 & 44.03 \\
\hline CML343 $\times 87036$ & 3306.36 & 68.50 & 2.60 & 568.73 & 43.41 & 3.25 & 172.00 & 2.95 & 40.59 \\
\hline $4001 \mathrm{STR} \times 87036$ & 3290.93 & 66.50 & 3.20 & 543.45 & 43.25 & 3.60 & 163.67 & 2.80 & 41.08 \\
\hline CLQRCWQ26 × 87036 & 3288.68 & 64.70 & 2.90 & 558.68 & 38.54 & 3.55 & 169.83 & 2.70 & 39.60 \\
\hline CML $444 \times \operatorname{Exp} 124$ & 3275.13 & 71.70 & 2.60 & 529.34 & 40.32 & 3.65 & 160.80 & 3.05 & 34.98 \\
\hline V-481-73 × Exp1 24 & 3255.76 & 68.90 & 3.60 & 559.71 & 44.10 & 2.60 & 165.10 & 2.63 & 27.28 \\
\hline CML343 × Exp1 24 & 3242.41 & 68.20 & 3.60 & 527.04 & 40.78 & 3.25 & 160.63 & 2.75 & 32.53 \\
\hline Cam inb gp1 $17 \times 87036$ & 3227.94 & 66.00 & 3.70 & 556.25 & 37.12 & 3.40 & 169.90 & 2.65 & 43.77 \\
\hline CML343 × 9071 & 3224.32 & 69.00 & 2.50 & 509.90 & 41.94 & 3.60 & 171.08 & 2.75 & 41.72 \\
\hline \multicolumn{10}{|l|}{ Best checks } \\
\hline $87036 \times$ Exp 124 & 2866.47 & 69.90 & 3.70 & 521.43 & 43.03 & 3.45 & 175.10 & 2.75 & \\
\hline Exp1 $24 \times 9071$ & 2336.64 & 67.30 & 2.70 & 548.51 & 37.71 & 3.90 & 160.15 & 3.10 & \\
\hline Mean & 2721.49 & 66.98 & 3.18 & 525.59 & 40.80 & 3.53 & 163.46 & 3.05 & \\
\hline Min & 1539.3 & 62.50 & 1.90 & 404.93 & 31.50 & 2.60 & 135.00 & 2.35 & \\
\hline Max & 3770.5 & 71.70 & 4.90 & 626.59 & 46.22 & 4.40 & 182.92 & 4.05 & \\
\hline LSD (0.05) & 1687.9 & 5.32 & 2.42 & 152.05 & 9.51 & 1.53 & 30.42 & 1.07 & \\
\hline
\end{tabular}

Note. ${ }^{*},{ }^{*}$, Significant at 0.05 and 0.01 probability levels, respectively, and ns, not significant; DTS $=$ days to $50 \%$ silking; ASI $=$ anthesis-silking interval; LAREA $=$ Ear leaf area; CHLORO $=$ leaf chlorophyll content; $\mathrm{LSENE}=$ leaf senescence $\mathrm{PHT}=$ plant height; $\mathrm{EA}=$ ear aspect, $\mathrm{YIELD}=$ grain yield. 
Table 3. Means for grain yield and other agronomic traits of best 20 hybrids and checks under high $\mathrm{N}$

\begin{tabular}{|c|c|c|c|c|c|c|c|}
\hline Hybrids & $\begin{array}{l}\text { YIELD } \\
\left(\mathrm{kg} \mathrm{ha}^{-1}\right)\end{array}$ & $\begin{array}{l}\text { DTS } \\
\text { (days) }\end{array}$ & $\begin{array}{l}\text { ASI } \\
\text { (days) }\end{array}$ & $\begin{array}{l}\text { LAREA } \\
\left(\mathrm{cm}^{2}\right)\end{array}$ & $\begin{array}{l}\text { CHLORO } \\
(\%)\end{array}$ & $\begin{array}{l}\text { PHT } \\
(\mathrm{cm})\end{array}$ & EA (1-5) \\
\hline TL-11-A-1642-5 × 87036 & 6588.84 & 65.20 & 1.70 & 650.86 & 51.08 & 193.57 & 2.40 \\
\hline CLYN246 × 87036 & 6584.97 & 63.40 & 2.20 & 740.32 & 54.19 & 197.70 & 2.05 \\
\hline TZ-STR-133 × 87036 & 6393.32 & 62.50 & 2.50 & 582.73 & 51.64 & 194.03 & 2.40 \\
\hline CLWN201 × Exp1 24 & 6152.26 & 63.10 & 2.00 & 617.83 & 49.52 & 174.17 & 2.05 \\
\hline J16-1 × Exp1 24 & 6048.74 & 63.00 & 2.20 & 652.95 & 47.84 & 174.97 & 2.10 \\
\hline CLQRCWQ26 × Exp1 24 & 5968.82 & 64.90 & 2.30 & 606.80 & 47.04 & 174.40 & 2.10 \\
\hline $1368 \times 87036$ & 5923.65 & 64.30 & 2.00 & 625.94 & 48.64 & 195.30 & 2.10 \\
\hline CLA $18 \times$ Exp1 24 & 5909.70 & 64.20 & 2.00 & 635.94 & 48.63 & 168.81 & 2.05 \\
\hline $4001 \mathrm{STR} \times 9071$ & 5792.07 & 63.00 & 2.20 & 645.79 & 48.67 & 177.80 & 2.45 \\
\hline $\mathrm{J} 16-1 \times 87036$ & 5780.49 & 63.70 & 1.90 & 654.25 & 51.02 & 181.73 & 2.30 \\
\hline CML395 × Exp1 24 & 5772.47 & 66.30 & 2.10 & 656.09 & 45.69 & 177.13 & 2.35 \\
\hline ATP S6-20-Y-1 × 87036 & 5765.88 & 63.60 & 1.60 & 671.13 & 52.65 & 198.03 & 1.90 \\
\hline Cam inb gp1 $17 \times 87036$ & 5741.05 & 64.60 & 2.90 & 614.06 & 55.90 & 196.33 & 1.85 \\
\hline CML451 × 87036 & 5729.07 & 66.30 & 2.70 & 616.98 & 47.88 & 187.50 & 2.45 \\
\hline CLYN246 × Exp1 24 & 5708.79 & 63.40 & 2.10 & 677.84 & 50.52 & 175.92 & 2.15 \\
\hline CML $358 \times 87036$ & 5699.02 & 65.60 & 2.30 & 644.87 & 46.79 & 197.07 & 2.40 \\
\hline CLA $18 \times 87036$ & 5694.14 & 64.20 & 2.20 & 663.14 & 54.10 & 199.67 & 2.15 \\
\hline $88069 \times 9071$ & 5687.94 & 62.30 & 2.40 & 709.45 & 53.63 & 188.73 & 2.40 \\
\hline ATP S5 31 Y-2 × 87036 & 5682.27 & 63.50 & 2.30 & 639.69 & 51.14 & 180.47 & 2.40 \\
\hline ATP S6-20-Y-1 × Exp1 24 & 5665.37 & 63.60 & 2.10 & 668.94 & 47.33 & 178.10 & 2.30 \\
\hline \multicolumn{8}{|l|}{ Best checks } \\
\hline $87036 \times$ Exp1 24 & 5169.43 & 64.60 & 2.50 & 655.17 & 49.73 & 185.60 & 2.35 \\
\hline Exp1 $24 \times 9071$ & 5262.24 & 68.20 & 2.10 & 680.24 & 47.74 & 176.23 & 2.90 \\
\hline Mean & 4887.18 & 64.73 & 2.26 & 630.63 & 49.96 & 182.27 & 2.50 \\
\hline Min & 3026.50 & 61.20 & 1.60 & 472.70 & 43.02 & 153.23 & 1.85 \\
\hline Max & 6588.80 & 69.40 & 3.10 & 772.06 & 55.90 & 210.07 & 3.50 \\
\hline LSD (0.05) & 2236.60 & 4.89 & 1.48 & 176.02 & 9.82 & 34.55 & 0.93 \\
\hline
\end{tabular}

Note. ${ }^{*}, * *$, Significant at 0.05 and 0.01 probability levels, respectively, and ns, not significant; DTS = days to $50 \%$ silking; ASI $=$ anthesis-silking interval; LAREA $=$ Ear leaf area; $\mathrm{CHLORO}=$ leaf chlorophyll content; PHT $=$ plant height $; \mathrm{EA}=$ ear aspect, YIELD $=$ grain yield. 
Table 4. Line $\times$ tester analysis for grain yield and agronomic traits across low $\mathrm{N}$ environments and percentage contribution of GCA and SCA to the total sum of squares

\begin{tabular}{|c|c|c|c|c|c|c|c|c|c|}
\hline Source of variation & df & $\begin{array}{l}\text { YIELD } \\
\left(\mathrm{kg} \mathrm{ha}^{-1}\right)\end{array}$ & $\begin{array}{l}\text { DTS } \\
\text { (days) }\end{array}$ & $\begin{array}{l}\text { ASI } \\
\text { (days) }\end{array}$ & $\begin{array}{l}\text { LAREA } \\
\left(\mathrm{cm}^{2}\right)\end{array}$ & $\begin{array}{l}\text { CHLORO } \\
(\%)\end{array}$ & $\begin{array}{l}\text { LSENE } \\
(1-9)\end{array}$ & $\begin{array}{l}\text { PHT } \\
(\mathrm{cm})\end{array}$ & EA (1-5) \\
\hline Env & 4 & $115584228.4^{*}$ & $2565.56^{* *}$ & $150.00 * *$ & $916162.69 * *$ & $12249.75 *$ & $64.57 \mathrm{~ns}$ & $130530.30 * *$ & $2.24 \mathrm{~ns}$ \\
\hline Rep (Env) & 5 & $18845743.3 * *$ & $57.41 \mathrm{~ns}$ & $4.42 \mathrm{~ns}$ & $59773.79 \mathrm{~ns}$ & $2075.55 * *$ & $26.63 * *$ & $1803.32 \mathrm{~ns}$ & $2.93 *$ \\
\hline Crosses & 116 & $1604070.5^{* *}$ & $21.31 * *$ & $2.46^{* *}$ & $13004.16^{* *}$ & $61.88^{* *}$ & $1.06 * *$ & $660.13 * *$ & $0.84 * *$ \\
\hline Env $\times$ Crosses & 464 & $1281639.8 * *$ & $9.30 *$ & $1.91 *$ & $9364.79 * *$ & $31.93 *$ & $0.75 *$ & $395.42 * *$ & $0.47 * *$ \\
\hline Line (GCA) & 38 & $2033201.1 * *$ & $38.82 * *$ & $3.40 * *$ & $17208.56^{* *}$ & $67.92 * *$ & $1.32 * *$ & $629.38 * *$ & $1.06^{* *}$ \\
\hline Tester (GCA) & 2 & $6836645.8 * *$ & $0.94 \mathrm{~ns}$ & $4.11 \mathrm{~ns}$ & $16265.33 \mathrm{~ns}$ & $305.68^{* *}$ & $10.93 * *$ & $13490.22 * *$ & $3.44 * *$ \\
\hline Line $\times$ Tester $(\mathrm{SCA})$ & 76 & $1227344 * *$ & $11.58 * *$ & $2.08^{*}$ & $11138.17 * *$ & $48.92 * *$ & $0.71 \mathrm{~ns}$ & $317.82 \mathrm{~ns}$ & $0.64 * *$ \\
\hline Env $\times$ Line $(\mathrm{GCA})$ & 152 & $1586891.9 * *$ & $8.83 \mathrm{~ns}$ & $2.18 * *$ & $9477.26^{* *}$ & $37.02 * *$ & $0.79 *$ & $365.82 *$ & $0.62 * *$ \\
\hline Env $\times$ Tester $(\mathrm{GCA})$ & 8 & $1824558.9^{*}$ & $24.08 * *$ & $1.15 \mathrm{~ns}$ & $15949.62 *$ & $59.08 * *$ & $1.03 \mathrm{~ns}$ & $1509.20 * *$ & $0.48 \mathrm{~ns}$ \\
\hline Env $\times$ Line $\times$ Tester $($ SCA $)$ & 304 & $1095883.3 * *$ & $9.16^{*}$ & $1.74 \mathrm{~ns}$ & $8863.19 * *$ & $27.85 \mathrm{~ns}$ & $0.72 \mathrm{~ns}$ & $365.70 * *$ & $0.39 * *$ \\
\hline Error & 689 & 770917 & 7.56 & 1.53 & 6477.74 & 25.99 & 0.62 & 283.15 & 0.3 \\
\hline$\%$ GCA SS (Line) & & 41.52 & 64.95 & 44.38 & 43.35 & 35.96 & 40.99 & 31.23 & 41.26 \\
\hline \%GCA SS (Tester) & & 7.35 & 0.11 & 2.88 & 2.16 & 8.52 & 17.84 & 35.23 & 7.03 \\
\hline$\%$ SCA SS $($ Line $\times$ Tester $)$ & & 50.13 & 35.48 & 55.34 & 56.12 & 51.80 & 43.92 & 31.54 & 49.40 \\
\hline
\end{tabular}

Note. ${ }^{*}, * *$, Significant at 0.05 and 0.01 probability levels, respectively, and ns, not significant; DTS $=$ days to $50 \%$ silking; ASI = anthesis-silking interval; LAREA = Ear leaf area; CHLORO = leaf chlorophyll content; LSENE = leaf senescence PHT = plant height; EA $=$ ear aspect, YIELD $=$ grain yield; GCA $=$ general combining ability; $\mathrm{SCA}=$ specific combining ability; $\mathrm{SS}=$ sum of squares.

Table 5. Line $\times$ tester analysis for grain yield and other agronomic traits across high $\mathrm{N}$ environments and percentage contribution of GCA and SCA to the total sum of squares

\begin{tabular}{|c|c|c|c|c|c|c|c|c|}
\hline Source of variation & df & $\begin{array}{l}\text { YIELD } \\
\left(\mathrm{kg} \mathrm{ha}^{-1}\right)\end{array}$ & $\begin{array}{l}\text { DTS } \\
\text { (days) }\end{array}$ & $\begin{array}{l}\text { ASI } \\
\text { (days) }\end{array}$ & $\begin{array}{l}\text { LAREA } \\
\left(\mathrm{cm}^{2}\right)\end{array}$ & $\begin{array}{l}\text { CHLORO } \\
(\%)\end{array}$ & $\begin{array}{l}\text { PHT } \\
\text { (cm) }\end{array}$ & EA (1-5) \\
\hline Env & 4 & $113613785.2 *$ & $152.37 \mathrm{~ns}$ & $14.48^{* *}$ & $1253297.66^{* *}$ & $707.94 \mathrm{~ns}$ & $158316.66^{*}$ & $4.12 \mathrm{~ns}$ \\
\hline Rep (Env) & 5 & $23958606.9 * *$ & $63.79 * *$ & $0.57 \mathrm{~ns}$ & $91730.79 * *$ & $189.13 *$ & $26106.28 * *$ & $2.19^{* *}$ \\
\hline Crosses & 116 & $4235566.4 * *$ & $18.05^{* *}$ & $0.72 \mathrm{~ns}$ & $18531.24 * *$ & $41.88^{* *}$ & $877.13 * *$ & $0.87 * *$ \\
\hline Env $*$ Crosses & 464 & $1840627.2^{* *}$ & $10.11^{* *}$ & $0.59 \mathrm{~ns}$ & $13091.60^{* *}$ & $30.38^{*}$ & $461.43 * *$ & $0.040^{* *}$ \\
\hline Line (GCA) & 38 & $5735295 * *$ & $31.32 * *$ & $0.92 *$ & $27262.50 * *$ & $50.34 * *$ & $864.85^{* *}$ & $1.10^{* *}$ \\
\hline Tester (GCA) & 2 & $27425796 * *$ & $52.36^{* *}$ & $0.95 \mathrm{~ns}$ & $33483.60 *$ & $608.21 * *$ & $17622.32 * *$ & $4.5^{* *}$ \\
\hline Line*Tester (SCA) & 76 & $2766032.3^{* *}$ & $9.89 * *$ & $0.61 \mathrm{~ns}$ & $13372.88^{*}$ & $22.97 \mathrm{~ns}$ & $401.10 \mathrm{~ns}$ & $0.67 * *$ \\
\hline Env*Line (GCA) & 152 & $2297712.1 * *$ & $11.97 * *$ & $0.57 \mathrm{~ns}$ & $16689.71 * *$ & $30.84 \mathrm{~ns}$ & $492.73 * *$ & $0.39 * *$ \\
\hline Env*Tester (GCA) & 8 & $3273204.3^{*}$ & $12.61 * *$ & $0.94 \mathrm{~ns}$ & $9156.18 \mathrm{~ns}$ & $104.76^{* *}$ & $1552.15^{* *}$ & $0.58^{*}$ \\
\hline Env*Line*Tester (SCA) & 304 & $1502318.4 \mathrm{~ns}$ & $8.68^{* *}$ & $0.59 \mathrm{~ns}$ & $11064.99 \mathrm{~ns}$ & $28.46 \mathrm{~ns}$ & $403.81 \mathrm{~ns}$ & $0.40 * *$ \\
\hline Error & 689 & 1292975 & 6.13 & 0.57 & 9877.4 & 26.3 & 360.33 & 0.24 \\
\hline$\%$ GCA SS (Lines) & & 44.36 & 56.68 & 42.15 & 48.19 & 39.38 & 32.30 & 41.24 \\
\hline \%GCA SS (Testers) & & 11.16 & 4.98 & 2.31 & 3.12 & 25.04 & 34.64 & 8.88 \\
\hline$\%$ SCA SS $($ Line $\times$ Tester $)$ & & 42.79 & 35.78 & 55.45 & 47.28 & 35.93 & 29.96 & 49.88 \\
\hline
\end{tabular}

Note. ${ }^{*}, * *$, Significant at 0.05 and 0.01 probability levels, respectively, and ns, not significant; DTS $=$ days to $50 \%$ silking; ASI = anthesis-silking interval; LAREA = Ear leaf area; $\mathrm{CHLORO}=$ leaf chlorophyll content; PHT $=$ plant height; $\mathrm{EA}=$ ear aspect, YIELD $=$ grain yield; $\mathrm{GCA}=$ general combining ability; $\mathrm{SCA}=$ specific combining ability; $\mathrm{SS}=$ sum of square. 
Table 6. Specific combining ability effects for grain yield and GCA effects of lines and testers under low and high $\mathrm{N}$ environments

\begin{tabular}{|c|c|c|c|c|c|c|c|c|}
\hline \multirow{3}{*}{ Lines } & \multicolumn{4}{|c|}{ Low $N$ environments } & \multicolumn{4}{|c|}{ High $\mathrm{N}$ environments } \\
\hline & \multicolumn{3}{|c|}{ Testers } & \multirow{2}{*}{ GCA lines } & \multicolumn{3}{|c|}{ Testers } & \multirow{2}{*}{ GCA lines } \\
\hline & 87036 & Exp1 24 & 9071 & & 87036 & Exp1 24 & 9071 & \\
\hline Cla 17 & -157 & 156.12 & 0.88 & -235.01 & 198.45 & 293.24 & -491.69 & $-197.43 *$ \\
\hline 9450 & 176.14 & -36.55 & -139.59 & $-865.88^{* *}$ & 97.77 & 532.12 & -629.89 & $-880.92 *$ \\
\hline 1368 & 39.78 & -114.17 & 74.4 & $468.23 *$ & -45.03 & 101.87 & -56.84 & $546.51^{*}$ \\
\hline M 131 & -314.4 & -141.49 & 455.89 & $-471.41^{*}$ & $-893.42 *$ & 301.29 & 592.13 & $-867.08^{* *}$ \\
\hline 88094 & 309.16 & -494.04 & 184.88 & -262.54 & 84.79 & -471.23 & 386.44 & $-569.49 *$ \\
\hline J18-1 & 196.68 & -317.1 & 120.42 & -355.27 & $905.58^{*}$ & -65.83 & $-839.75^{*}$ & $-650.35 * *$ \\
\hline 88069 & -39.04 & -90.83 & 129.87 & 275.61 & -569.85 & 93.37 & 476.48 & 367.32 \\
\hline Entrada 29 & $-721.19^{*}$ & 452.43 & 268.76 & -215.15 & -498.58 & 358.29 & 140.28 & $-501.27 *$ \\
\hline CML 358 & 16.68 & 506.33 & -523.02 & -321.81 & 570.35 & 394.44 & $-964.79 *$ & -146.94 \\
\hline Entrada 3 & 265.88 & -131.26 & -134.62 & -158.03 & 138.63 & -330.23 & 191.6 & $-470.78^{*}$ \\
\hline CML 254 & 162.89 & -62.79 & -100.1 & 19.99 & -643.06 & 508.75 & 134.32 & 84.29 \\
\hline 5012 & -116.73 & 110.06 & 6.68 & -103.65 & -115.8 & 254.75 & -138.95 & -341.08 \\
\hline Cam inb gp1 17 & 86.6 & -27.92 & -58.68 & 253.52 & 158.46 & -166.89 & 8.43 & 259.45 \\
\hline 9848 & 130.24 & -411.97 & 281.73 & $-436.20^{*}$ & 27.2 & -307.46 & 280.26 & -329.05 \\
\hline CLA 18 & 155.1 & -68.81 & -86.29 & 208.75 & 213.51 & 678.56 & $-892.06 *$ & 217.99 \\
\hline ATP S9 30 Y-1 & 280.4 & 155.38 & -435.78 & $436.48^{*}$ & 634.38 & -89.83 & -544.55 & -431.89 \\
\hline ATP S5 31 Y-2 & 20.8 & -130.12 & 109.33 & 106.39 & 173.48 & -388.74 & 215.25 & 308.32 \\
\hline KU1414 & 313.07 & -272.61 & -40.46 & -123.14 & -111.2 & -58.53 & 169.73 & 274.74 \\
\hline 5057 & 30.32 & -98.44 & 68.13 & -334.54 & -536.08 & 394.34 & 141.74 & -235.7 \\
\hline ATP S6 20 Y-2 & -507.06 & $679.45^{*}$ & -172.39 & 185.23 & $-795.1^{*}$ & 339.79 & 455.31 & -84.51 \\
\hline ATP S8 30 Y-3 & -187.49 & -6.86 & 194.36 & -62.55 & 20.04 & -9.05 & -10.99 & 185.93 \\
\hline CLWN201 & 275.45 & -202.25 & -73.2 & $483.80^{* *}$ & -221.98 & 143.04 & 78.94 & $720.74 * *$ \\
\hline TZMI 102 & -355.56 & 344.13 & 11.44 & -88.74 & 144.77 & -11.23 & -133.54 & -240.31 \\
\hline $\mathrm{J} 16-1$ & -115.2 & 303.93 & -188.73 & 326.14 & -337.17 & 332.91 & 4.26 & $728.75^{* *}$ \\
\hline CLYN246 & 503.41 & -456.75 & -46.67 & 300.65 & 278.32 & -232.95 & -45.37 & $982.75^{* *}$ \\
\hline CML395 & -480.61 & 229.27 & 251.34 & -283.85 & $-888.88^{*}$ & 621.06 & 267.82 & 125.17 \\
\hline CML494 & -198.48 & -427.93 & $626.403 *$ & -299.82 & 45 & $-808.92 *$ & 763.92 & -16.75 \\
\hline CML165 & 518.95 & -355.12 & -163.83 & -46.53 & 212.11 & -43.25 & -168.86 & -59.51 \\
\hline CLQRCWQ26 & -109.46 & 159.52 & -50.06 & $396.45^{*}$ & -290.71 & 409.14 & -118.43 & $640.10^{* *}$ \\
\hline CML451 & 187.95 & -374.18 & 186.23 & 85.04 & 548.87 & -497.01 & -51.85 & 19.49 \\
\hline V-351-1/6 & -31.49 & -43.26 & 74.75 & -165.15 & -285.87 & -229.37 & 515.24 & $-557.39^{*}$ \\
\hline V-481-73 & -594.49 & 602.76 & -8.27 & -293.94 & -263.1 & 309.21 & -46.11 & $-751.85^{* *}$ \\
\hline TZ-STR-133 & -272.85 & 120.64 & 152.21 & 121.22 & $893.04 *$ & -624.02 & -269.02 & 339.57 \\
\hline TL-11-A-1642-5 & 51.38 & $648.395^{*}$ & $-699.77 *$ & 326.73 & 752.27 & -176.46 & -575.81 & $675.86^{* *}$ \\
\hline Ku1409 & 28.66 & -16.79 & -11.86 & 15.45 & 235.94 & -392.6 & 156.66 & -26.32 \\
\hline ATP S6-20-Y-1 & -98.84 & 65.49 & 33.35 & $504.46^{* *}$ & 66.98 & 207.6 & -274.58 & $538.19^{*}$ \\
\hline CML343 & -23.52 & -75.23 & 98.76 & $522.26 * *$ & 1.66 & -516.69 & 515.03 & 402.9 \\
\hline CML 444 & 165.75 & 468.08 & $-633.83^{*}$ & 11.67 & -140.04 & 367.64 & -227.6 & -250.34 \\
\hline 4001STR & 408.16 & $-645.52 *$ & 237.37 & 75.15 & 234.29 & $-1221.11^{*}$ & $986.82 *$ & 190.86 \\
\hline GCA Testers & 72.19 & 59.95 & $-132.13 * *$ & & $262.49 * *$ & $21.36 * *$ & $-283.84 * *$ & \\
\hline
\end{tabular}

Note. ${ }^{*}, * *$, Significant at 0.05 and 0.01 probability levels, respectively, and ns, not significant; SCA: Specific combining ability.

\section{Discussion}

The results of this study revealed that six hybrids yielded more than $3500 \mathrm{~kg} \cdot \mathrm{ha}^{-1}$ under low $\mathrm{N}$ condition. These include TL-11-A-1642-5 × Exp1 24, CLWN201 × 87036, ATP S6 20 Y-2 × Exp1 24, J16-1 × Exp1 24, ATP S9 
30 Y-1 $\times$ Exp1 24 and CLYN246 $\times 87036$. The best hybrid among the four checks evaluated was $87036 \times$ Exp 1 24 , and the performance of this hybrid under low $\mathrm{N}$ was similar to that obtained $\left(3 \mathrm{tha}^{-1}\right)$ by The et al. (2013). Under low $\mathrm{N}$, significant differences were observed among the hybrids for all traits, indicating the variable reaction of the tested genotypes to low N stress. Similar results were obtained by Ifie et al. (2014) under low N. The use of inbred lines from diverse sources of germplasm for generation of the crosses might have contributed to the significant difference observed among crosses for most of the traits considered. Under high $\mathrm{N}$ environments, the five highest yielding hybrids were TL-11-A-1642-5 $\times 87036$, CLYN246 $\times 87036$, TZ-STR-133 × 87036, CLWN201 $\times$ Exp1 24, and J16-1 × Exp1 24. Each yielded more than $6000 \mathrm{~kg} \mathrm{ha}^{-1}$. Under both low and high $\mathrm{N}$ environments, the best yielding hybrids out-yielded the four checks among which is the commercial hybrid $(87036 \times$ Exp1 24) for the Humid Forest Zone of Cameroon. These could be candidates for release.

In this study, six hybrids were selected from the 20 best hybrids under both low $\mathrm{N}$, high $\mathrm{N}$ and across environments. These included CLYN246 × 87036, CLWN201 × Exp1 24, J16-1 × Exp1 24, $1368 \times 87036$, ATP S6-20-Y-1 $\times$ Exp1 24 and Cam inb gp1 $17 \times 87036$. They appear to be $10 \%$ better than the best check. Exp1 24 appears to be an excellent line and could be used as a tester for source populations between TL-11-A-1642-5, ATP S6 20 Y-2, J16-1, and ATP S9 30 Y-1. CLWN201 and CLYN246 could be recombined to form a source population with 87036 as the tester.

Under low $\mathrm{N}$, high $\mathrm{N}$ and across environments, the majority of hybrids selected for high grain yield had one CIMMYT line and one line developed by the Cameroon national breeding program as parental lines. This suggests that these introduced lines from CIMMYT and those from IRAD are genetically diverse. This result is in agreement with the statement that the development of adapted high yielding hybrids requires that the varieties used as parents are genetically divergent as highlighted in Acquaah (2007).

GCA effects are associated with additive gene effect while SCA effects are associated with non-additive gene action. The results obtained under low $\mathrm{N}$ showed that mean squares of both GCA and SCA were significant for all traits except leaf senescence and plant height. This suggests that, except for these two traits, all other traits were controlled by both additive and non-additive gene effects. Furthermore, non-additive gene effect was predominant in the control of grain yield, anthesis-silking interval, leaf chlorophyll content and ear aspect while days to silking, leaf senescence and plant height were influenced mainly by additive gene effects. Similar results on grain yield were earlier reported by Betràn et al. (2003), Gama et al. (2002), Mosisa et al. (2008), Makumbi et al. (2011), Meseka et al. (2006, 2013), and Ndhlela (2012). However, these results are contradictory to those of Below et al. (1997), Kling et al. (1997), Badu-Apraku et al. (2011, 2013), Ifie et al. (2014) and Tamilarasi et al. (2010) who reported predominance of additive gene effects compared to non-additive gene effects for grain yield under low $\mathrm{N}$. The contradictory results might be due to the difference in environments $(\mathrm{N}$ stress level) under which the genotypes were tested or genotypic differences among sets of genotypes included in the studies as suggested by Mosisa et al. (2008). This might also be due to the difficulties that statistical models have in predicting non-additive gene effects. The predominance of non-additive genetic effects for grain yield and other traits observed in this set of inbred lines suggests that hybrid development could be employed under low $\mathrm{N}$ in order to exploit non-additive gene effect which is based on over dominance and epistasis, being more predictive of heterotic potential.

It was also found that under high $\mathrm{N}$ environments, grain yield, days to silking, leaf area and ear aspect were controlled by both additive and non-additive gene effects. Additive gene effect was predominant in the control of all traits except anthesis-silking interval. The higher magnitude of additive gene effects under high $\mathrm{N}$ is consistent with the findings of Below et al. (1997), De Souza et al. (2008) and Makumbi et al. (2011). The significant GCA x environment interaction for grain yield and other traits indicates that GCA effects associated with the lines and testers were not consistent over environments.

Lines with best GCA for grain yield under low N were CML 343, ATP S6 20-Y1, CLWN201 1368, ATP S9 30 Y-1 and CLQRCWQ26. The good general combining ability under low N of CLWN201 and CLQRCWQ26 from CIMMYT are in agreement with the description given by CIMMYT (2014). CML343, another line from CIMMYT, was also identified by Makumbi et al. (2011) as a good general combiner for grain yield across all environments in a study of combining ability under low $\mathrm{N}$, drought and well-watered environments. Three lines in this study were also the best general combiners under high N conditions; these are CLWN201, 1368 and CLQRCWQ26. Cla 17 was the best general combiner for days to silking under low $\mathrm{N}$ and high $\mathrm{N}$ conditions, whereas 5012 was best combiner in both environments for plant height. The best combiners for shorter anthesiilking interval were Cla 17 under low N and ATPS6 20 Y-1 under high N environments. A shorter anthesis-silking interval under low $\mathrm{N}$ may imply that the varieties are able to synchronise pollen shedding with 
silk emergence (Ndhlela, 2012). A reduced anthesis-silking interval is a sign of improved partitioning of assimilates to ears around flowering time (Edmeades et al., 1993). The best combiners for larger leaf area were CLQRCWQ26 under low N and CML343 under high N environments. A larger leaf area could imply a better interception of light by the plant for photosynthesis. These lines identified as best combiners could be used as parents in a breeding program to improve the respective traits as suggested by Girma et al. (2015).

Testers 87036 and Exp1 24 are good general combiners compared to 9071 for grain yield and other traits except for days to anthesis and days to silking. This suggests that under low N, 87036 and Exp1 24 are more capable of contributing alleles for improvement of these traits to hybrids.

\section{Conclusions}

The results of this study suggest that there is genetic variability among the hybrids evaluated, making it possible to identify desirable hybrids for grain yield and other agronomic traits under low Nitrogen $(\mathrm{N})$ conditions. Many hybrids out-yielded $87036 \times$ Exp1 24 (commercial hybrid used as check) in the study. Among these, three hybrids $($ CLWN201 $\times \operatorname{Exp1~24,~J16-1~} \times$ Exp1 24, and $1368 \times 87036)$ were identified as higher yielding than the best check under low $\mathrm{N}$, high $\mathrm{N}$ and across environments and are candidates for release. For specific areas with low $\mathrm{N}$ stress or for farmers who cannot afford N fertilizer, TL-11-A-1642-5 $\times$ Exp1 24, CLWN201 $\times 87036$ and J16-1 $\times$ Exp1 24 may be candidates for release as low N tolerant hybrids. Moreoevr, TL-11-A-1642-5 $\times 87036$, TZ-STR-133 $\times$ 87036, CLWN201 $\times$ Exp1 24 and J16-1 $\times$ Exp1 24 could be proposed for high $\mathrm{N}$ conditions after undergoing additional evaluations.

Under low $\mathrm{N}$ and high $\mathrm{N}$ environments, grain yield and most traits were controlled by both additive and non-additive gene effects with predominance of non-additive gene effect under low $\mathrm{N}$ and additive gene effect under high $\mathrm{N}$ conditions. Good hybrid development could be achieved under low N through exploitation of this non-additive gene effect, predictive of heterosis. Due to the influence of non-additive gene effect, SCA of crosses could be used together with means for grain yield to classify inbred lines into heterotic groups. In this study, the best general combiners found for grain yield under both low and high $\mathrm{N}$ conditions could be used as parents in a breeding program to develop high yielding hybrids for low and high $\mathrm{N}$ environments. In each of these environments, the parents identified for good SCA could effectively be included in hybrid breeding programs for the improvement of grain yield.

In conclusion, the better performing testcrosses, inbred lines with desirable GCA and cross combinations with desirable SCA effects for grain yield and other agronomic traits identified under low and/or high $\mathrm{N}$ conditions could constitute a source of valuable genetic material for use in future breeding work.

\section{Acknowledgements}

Many Thanks to the Alliance for Green Revolution in Africa (AGRA) for sponsoring this study through the West Africa Centre for Crop Improvement (WACCI), University of Ghana. We are grateful to IITA and CIMMYT for supplying the germplasm used. The contribution of Professor Hussein Shimelis from University of KwaZulu-Natal to this manuscript is highly appreciated.

\section{References}

Abrha, S. W., Habtamu, Z. Z., \& Dagne, W. G. (2013). Line $\times$ tester analysis of maize inbred lines for grain yield and yield related traits. Asian J Plant Sci Res, 3, 12-19. Retrieved from http://www.pelagiaresearch library.com

Acquaah, G. (2007). Principles of Plant Genetics and Breeding. Blackwell Publishing, UK.

Aly, R. S. H. (2013). Relationship between combining ability of grain yield and yield components for some newly yellow maize inbred lines via Line $\times$ Tester analysis. Alex J Agric Res, 58, 115-124.

Badu-Apraku, B., \& Akinwale, R. (2011). Identification of early-maturing maize inbred lines based on multiple traits under drought and low $\mathrm{N}$ environments for hybrid development and population improvement. Can J Plant Sci, 91, 931-942. https://doi.org/10.4141/CJPS2010-021

Badu-Apraku, B., Oyekunle, M., Fakorede, M. A. B., Vroh, I., Akinwale, R. O., \& Aderounmu, M. (2013). Combining ability, heterotic patterns and genetic diversity of extra-early yellow inbreds under contrasting environments. Euphytica, 192, 413-433. https://doi.org/10.1007/s10681-013-0876-4

Beck, D. L., Vasal, S. K., \& Crossa, J. (1990). Heterosis and combining ability of CIMMYT's tropical early and intermediate maturity maize (Zea mays L.) germplasm. Maydica, 35, 279-285. Retrieved from http://repository.cimmyt.org/xmlui/handle/10883/1927?show=full 
Betràn, F. J., Beck, D., Bänziger, M., \& Edmeades, G. O. (2003). Genetic analysis of inbred and hybrid grain yield under stress and nonstress environments in tropical maize. Crop Sci, 43, 807-817. https://doi.org/10.2135/cropsci2003.8070

CIMMYT. (2014). CIMMYT releases 22 new maize inbred lines for the tropics and subtropics. Retrieved November 14, 2014, from http://www.cimmyt.org/en/what-we-do/maize-research/item/cimmyt-releases-22new-maize-inbred-lines-for-the-tropics-and-subtropics

Cochran, W. G., \& Cox, G. M. (1960). Experimental designs. John Wiley \& Sons New York, USA.

De Souza, L. V., Glauco, V. M., Galvão, J. C. C., Eckert, F. R., Mantovani, É. E., Lima R. O., \& Guimarães, L. J. M. (2008). Genetic control of grain yield and nitrogen use efficiency in tropical maize. Pesq Agropec Bra, Brasilia, 43, 1517-1523. https://doi.org/10.1590/S0100-204X2008001100010

Edmeades, G. O., Bolanos, J., Hernandez, M., \& Bello, S. (1993). Causes for silk delay in a lowland tropical maize population. Crop Sci, 33, 1029-1035. https://doi.org/10.2135/cropsci1993.0011183X003300050031x

FAOSTAT. (2014). FAO Statistics Division 2014. Retrieved December 8, 2014, from http://faostat.fao.org

Giauffret, C., Bonhomme, R., \& Derieux, M. (1997). Heterosis in maize for biomass production, leaf area establishment, and radiation use efficiency under cool, spring conditions. Maydica, 42, 13-19.

Girma, C. H., Sentayehu, A., Berhanu, T., \& Temesgen, M. (2015). Test cross performance and combining ability of maize (Zea mays L.) inbred lines at Bako, Western Ethiopia. GJSFR: D Agriculture and Veterinary, 15.

Hauser, S., \& Nolte, C. (2002). Biomass production and N fixation of five Mucuna pruriens varieties and their effect on maize yields in the forest zone of Cameroon. J Plant Nutr Soil Sci, 165, 101-109. https://doi.org/10.1002/1522-2624(200202)165:1\%3C101::AID-JPLN101\%3E3.0.CO;2-F

Ifie, B. E., Badu-Apraku, B., Gracen, V., \& Danquah, E. Y. (2014). Genetic analysis of grain yield of IITA and CIMMYT early-maturing maize inbreds under Striga-infested and low-soil-nitrogen environments. Crop Sci., 55, 610-623. https://doi.org/10.2135/cropsci2014.07.0470

IITA. (2014). Maize 2014. Retrieved June 16, 2014, from http://www.iita.org/maize

Kempthrone, O. (1957). An introduction to genetic statistics. John Willey and Sons, Inc, New York.

Majid, S., Rajab, C., Eslam, M., \& Farokh, D. (2010). Estimation of combining ability and gene action in maize using Line $\times$ Tester method under three irrigation regimes. JRAS, 6, 19-28.

Makumbi, D., Betràn, F. J., Bänziger, M., \& Ribaut, J. (2011). Combining ability, heterosis and genetic diversity in tropical maize (Zea mays L.) under stress and non-stress conditions. Euphytica, 180, $143-162$. https://doi.org/10.1007/s10681-010-0334-5

Meseka, S. K., Menkir, A., Ibrahim, A. E. S., \& Ajala, S. O. (2006). Genetic analysis of performance of maize inbred lines selected for tolerance to drought under low nitrogen. Maydica, 51, 487-495.

Meseka, S. K., Menkir, A., Ibrahim, A. E. S., \& Ajala, S. O. (2013). Genetic analysis of maize inbred lines for tolerance to drought and low nitrogen. JONARES, 1, 29-36.

Miti, F., Tongoona, P., \& Derera, J. (2010). S1 selection of local maize landraces for low soil nitrogen tolerance in Zambia. African Journal of Plant Science, 4(3), 067-081. Retrieved from http://www.academicjournals. org/ajps

Montgeomery, E. G. (1911). Correlation studies in corn. Nebraska Agr Exp Sta Annu Repr, 24, 108-159.

Mosisa, W., Bänziger, M., Friesen, D., Erley, S. A. G., Horst, W. J., \& Vivek, B. S. (2008). Relative importance of general combining ability and specific combining ability among tropical maize (Zea mays L.) inbreds under contrasting nitrogen environments. Maydica, 53, 279-288.

Ndhlela, T., Herselman, L., Semagn, K., Magorokosho, C., Mutimaamba, C., \& Labuschagne, M. T. (2015). Relationships between heterosis, genetic distances and specific combining ability among CIMMYT and Zimbabwe developed maize inbred lines under stress and optimal conditions. Euphytica, $204,635$. https://doi.org/10.1007/s10681-015-1353-z

Ngoko, Z., Cardwell, K. F., Marasas, W. F. O., Wingfield, M. J., Ndemah, R., \& Shulthess, F. (2002). Biological and physical constraints on maize production in the humid forest and Western Highlands of Cameroon. Eur J Plant Pathol, 108, 893-902. https://doi.org/10.1023/A:1021206028492 
Nguimgo, K. A. B., Balasubramanian, V., Kaho, F., \& Zeukeng, P. (2003). Maize-legume rotation and association for intensive maize production in the humid forest zone of Cameroon. In B. Badu-Apraku et al. (Eds.), Maize revolution in West and Central Africa (pp. 189-201). Proceedings of a regional maize workshop, May 14-18, 2001, IITA-Cotonou, Benin Republic. WECAMAN/IITA.

NUEweb. (2012). Maize, Rice, and Wheat area. World Wheat, Maize (Corn), Rice, and Cotton. Retrieved from http://nue.okstate.edu/Crop_Information/World_Wheat_Production.htm

Pswarayi, A., \& Vivek, B. S. (2008). Combining ability amongst CIMMYT's early maturing maize (Zea mays L.) germplasm under stress and non-stress conditions and identification of testers. Euphytica, 162, 353-362. https://doi.org/10.1007/s10681-007-9525-0

Sofi, P., \& Rather, A. G. (2006). Genetic Analysis of Yield Traits in Local and Cimmyt Inbred Line Crosses Using LinexTester Analysis in Maize (Zea mays L.). Asian Journal of Plant Sciences, 5, 1039-1042. https://doi.org/10.3923/ajps.2006.1039.1042

Tamilarasi, P. M., Arumugachamy, S., Anantha, M. S., \& Utharasu, S. (2010). Identification of Nitrogen (N) Stress Tolerant Maize (Zea Mays L.) Inbred Lines for Low Nitrogen Input Condition. Indian J Agr Res, 44, 53-57.

Tchienkoua, M. (1996). Soil and land-use survey of the northern section of the Mbalmayo forest reserve (Southern Cameroon): A study for the selection of the IITA Humid Forest Station site. In R.A.C.M.R.M.N. (Ed.), Humid Forest Station Report (No. 1, p. 65). International Institute of Tropical Agriculture, Ibadan.

The, C., Ngonkeu, M. L., Zonkeng, C., \& Apala, H. M. (2013). Evaluation and selection of maize (Zea mays L.) genotypes tolerant to low N soil. Optimizing Productivity of Food Crop Genotypes in Low Nutrient Soils. IAEA-TECDOC, 1721, 251-264.

Vasal, S. K., Cordova, H. S., Beck, D. L., \& Edmeades, G. O. (1997). Choices among breeding procedures and strategies for developing stress-tolerant maize germplasm. In G. O. Edmeades et al. (Eds.), Developing Drought- and Low N-Tolerant Maize. Proceedings of a Symposium (pp. 336-347). CIMMYT, El Batán, Mexico.

Vasal, S. K., Srinivasan, G., Han, G. C., \& Gonzalez, F. (1992). Heterotic patterns of eighty eight white subtropical CIMMYT maize lines. Maydica, 37, 319-327.

\section{Copyrights}

Copyright for this article is retained by the author(s), with first publication rights granted to the journal.

This is an open-access article distributed under the terms and conditions of the Creative Commons Attribution license (http://creativecommons.org/licenses/by/4.0/). 